\title{
Anti-inflammatory and Hypoglycemic Activities of Alpha-pinene
}

\author{
Hanefi Özbek ${ }^{1 *}$, Betül Sever Yılmaz² \\ ${ }^{1}$ Istanbul Medipol University, School of Medicine, Department of Medical Pharmacology \\ ${ }^{2}$ Ankara University, Faculty of Pharmacy, Department of Pharmacognosy
}

\section{ABSTRACT}

The aim of this study is to investigate the anti-inflammatory and hypoglycemic activities of alpha-pinene, and to find the median lethal dose $\left(\mathrm{LD}_{50}\right)$ level in mice.

Lethal dose levels of alpha-pinene were investigated using a probit analysis method. For the anti-inflammatory activity measurement seven different groups were established and alpha-pinene was administered in four different doses: 0.05, 0.10, 0.25 and $0.50 \mathrm{~mL} / \mathrm{kg}$. For the evaluation of hypoglycemic activity six different groups, consisting of diabetic and healthy mice, were established.

The strongest anti-inflammatory activity of alpha-pinene was observed with a 0.50 $\mathrm{mL} / \mathrm{kg}$ dosage. The median effective dose $\left(\mathrm{ED}_{50}\right)$ value of alpha-pinene was found to be $0.039 \mathrm{~mL} / \mathrm{kg}$. In diabetic mice $\alpha$-pinene showed significant levels of hypoglycemic activity at the $2^{\text {nd }}$ and $24^{\text {th }}$ hours. $\mathrm{LD}_{50}$ level of $\alpha$-pinene was determined to be $2.076 \mathrm{~mL} / \mathrm{kg}$.

As a result, we conclude that alpha-pinene is a molecule that displays hypoglycemic and anti-inflammatory activities.

Keywords: Alpha-pinene, anti-inflammatory activity, hypoglycemic activity, mice, rats.

\section{INTRODUCTION}

Foeniculum vulgare Miller, (family Umbelliferae) is an annual, biennial or perennial aromatic herb, depending on the variety, which has been known since antiquity in Europe and Asia Minor. The leaves, stalks and seeds (fruits) of the plant are edible ${ }^{1}$. Extracts of Foeniculum vulgare Miller (fennel) seeds are used as an anti-inflammatory agent in Turkish traditional medicine ${ }^{2}$. The antiinflammatory, hypoglycemic and hepatoprotective effects of fennel were dem-

*Corresponding author: Hanefi Özbek, e-mail: hozbek@medipol.edu.tr (Received 14 July 2017, accepted 31 July 2017) 
onstrated in previous studies ${ }^{3-7}$. The volatile components of fennel seed extracts are trans-anethole, fenchone, methylchavicol, limonene, alpha-pinene, camphene, $\beta$-pinene, $\beta$-myrcene, $\alpha$-phellandrene, 3 -carene, camphor, and cisanethole ${ }^{8}$. The major components of the fennel seed essential oil are alpha-pinene, limonene, fenchone, methychavicol and trans-anethole ${ }^{6}$.

In our previous work, we demonstrated the anti-inflammatory and hypoglycemic activities of volatile oil extract of fennel ${ }^{3-7}$. In order to determine the fennel component(s) responsible for these activities and to determine its lethal dose levels, this study investigates alpha-pinene, a major component of volatile oil extract of fennel.

\section{METHODOLOGY}

\section{Animals}

Sprague-Dawley rats and Mus musculus Swiss albino mice were maintained in the animal house. The animals were housed in standard cages with pelleted food and water ad libitum, at room temperature $\left(22 \pm 2^{\circ} \mathrm{C}\right)$ with a $12 \mathrm{~h}$ light-dark cycle. Ethical approval was obtained from the Animal Ethics Committee.

\section{Chemicals}

(1R)-(+)- $\alpha$-pinene $\left(\mathrm{C}_{10} \mathrm{H}_{16}\right)$, lambda-carrageenan Type IV, indomethacin and alloxan were obtained from Sigma (Steinheim, Germany), and glibenclamide was obtained from Nobel (Istanbul, Turkey).

\section{Acute toxicity}

Swiss albino mice were randomly assigned to nine groups with six animals in each group. The control group was treated with isotonic saline solution (ISS) $(0.9 \% \mathrm{NaCl})$, and the other eight groups were treated with alpha-pinene given intraperitoneally (ip) by Hamilton and insulin injectors in increasing dosages of 0.05, 0.10, 0.20, 0.40, 0.80, 1.60, 2.40 and $3.20 \mathrm{~mL} / \mathrm{kg}$ body weight. The mortality in each cage was assessed $72 \mathrm{~h}$ after administration of alpha-pinene. The percentage mortalities were converted to probits. Regression lines were fitted by the method of least squares and confidence limits for the $\mathrm{LD}_{1}, \mathrm{LD}_{10}, \mathrm{LD}_{50}, \mathrm{LD}_{90}$ and $\mathrm{LD}_{99}$ values were calculated by the method of Litchfield \& Wilcoxon ${ }^{9}$ and Kouadio et $\mathrm{al}^{10}$.

\section{Anti-inflammatory activity}

The method of Winter et al was used with slight modification ${ }^{11}$. Forty-two rats were divided into seven groups of six animals each. The rats were starved for 12 $\mathrm{h}$ and deprived of water only during the experiment. Water deprivation was em- 
ployed to ensure uniform hydration and to minimize variability in edematous response. Inflammation of the hind paw was induced by injecting $0.05 \mathrm{~mL}$ of fresh lambda carrageenan (phlogistic agent) into the subplantar surface of the right hind paw. The control group-I was given ISS (o.1 mL) and the control group-II was given ethyl alcohol (0.1 mL). The third group (reference group) received the anti-inflammatory agent indomethacin ( $3 \mathrm{mg} / \mathrm{kg}$, ip), while the remaining four groups received alpha-pinene at doses of $0.05,0.10,0.25$ and $0.50 \mathrm{~mL} / \mathrm{kg}$, i.p by Hamilton injector ${ }^{12}$. The doses utilized in the current study were chosen according to $\mathrm{LD}_{1}$ value $\left(\mathrm{LD}_{1}=0.744 \mathrm{~mL} / \mathrm{kg}\right)$.

Foot volume was measured by a displacement technique using a plethysmometer (Ugo Basile 7140 plethysmometer, Italy), immediately before and three hours after the $0.05 \mathrm{~mL}$ of fresh lambda carrageenan injection. The percentage inhibition of the inflammatory reaction was determined for each animal by comparison with controls and calculated by the formula ${ }^{10}$ :

I \% $=[(1-(\mathrm{dt} / \mathrm{dc})] \times 100$

where $d t$ is the difference in paw volume in the drug-treated group and $d c$ the difference in paw volume in the control group.

\section{Preparation of alloxan diabetic mice}

Diabetes was induced by i.p. injections of $150 \mathrm{mg} / \mathrm{kg}$ alloxan monohydrate prepared in ISS three times with $48 \mathrm{~h}$ intervals. Before injections were given mice were starved for $18 \mathrm{~h}^{13}$. Seven days after the last injection, fasting blood glucose levels were measured and mice with fasting blood glucose levels of $200 \mathrm{mg} / \mathrm{dL}$ and over were taken into the study ${ }^{14}$.

\section{Hypoglycemic activity in normal and diabetic mice}

Diabetic animals were randomly divided into three groups of six animals each. Group I mice received o.1 mL ISS i.p. The animals in group II were treated orally with $3.0 \mathrm{mg} / \mathrm{kg}$ glibenclamide, a hypoglycemic agent, used as reference. Group III received i.p. injection of $0.25 \mathrm{~mL} / \mathrm{kg}$ alpha-pinene by Hamilton injector. The same protocol described above was applied in three groups of normal mice. Fasting blood glucose levels were measured after $18 \mathrm{~h}$ of fasting just before the treatment and 1, 2, 4 and $24 \mathrm{~h}$ after the treatment using the glucose oxidase peroxidase method (Abbott, United Kingdom).

\section{Statistical analysis}

Results were reported as mean \pm standard error of mean (SEM). The total variation was analyzed by performing a one-way analysis of variance (ANOVA). Least Significant Difference (LSD) test, Dunnet test and Tukey's HSD (Honestly 
Significant Difference) test were used for determining significance. Probability levels of less than 0.05 were considered significant. The medium effective dose $\left(\mathrm{ED}_{50}\right)$ value was calculated by non-linear regression analysis (SigmaPlot 2004 for Windows Version 9.01).

\section{RESULTS AND DISCUSSION}

\section{Acute toxicity}

The lethal doses of alpha-pinene are presented in Table 1. The intraperitoneal medium lethal dose $\left(\mathrm{LD}_{50}\right)$ value for the total number of animals was found to be $2.076 \mathrm{~mL} / \mathrm{kg}$.

Table 1. Lethal doses of (1R)-(+)- $\alpha$-pinene $\left(\mathrm{C}_{10} \mathrm{H}_{16}\right)$.

\begin{tabular}{llll}
\hline & \multirow{2}{*}{$\begin{array}{l}\text { Dose } \\
(\mathbf{m L} / \mathbf{k g})\end{array}$} & \begin{tabular}{l} 
$95 \%$ confidence limits \\
\cline { 3 - 4 }$(\mathbf{m L} / \mathbf{k g})$
\end{tabular} & $\begin{array}{l}\text { Upper } \\
(\mathbf{m L} / \mathbf{k g})\end{array}$ \\
\hline $\mathrm{LD}_{1}$ & 0.744 & 0.012 & 1.242 \\
\hline $\mathrm{LD}_{10}$ & 1.179 & 0.111 & 1.663 \\
\hline $\mathrm{LD}_{50}$ & 2.076 & 1.246 & 3.180 \\
\hline $\mathrm{LD}_{90}$ & 3.655 & 2.630 & 32.295 \\
\hline $\mathrm{LD}_{99}$ & 4.497 & 3.023 & 86.301 \\
\hline
\end{tabular}

\section{Anti-inflammatory activity}

Table 2 shows the anti-inflammatory effects of intraperitoneally administered alpha-pinene on carrageenan induced paw edema in rats. Alpha-pinene showed significant anti-inflammatory effect in two doses studied $(0.025 \mathrm{~mL} / \mathrm{kg}$ and 0.50 $\mathrm{mL} / \mathrm{kg}$ ); peak response was obtained with $0.50 \mathrm{~mL} / \mathrm{kg}$ alpha-pinene $(60.33 \%$ decrease in inflammation) and $0.05 \mathrm{~mL} / \mathrm{kg}$ alpha-pinene caused a lesser degree of inhibition of the inflammation (18.97\%). Compared to the controls, the greatest anti-inflammatory activity was observed in the indomethacin group, with a 87.44\% regression of the inflammation. Compared to indomethacin group, alpha-pinene group had significantly lower anti-inflammatory effects at all doses. At $0.05 \mathrm{~mL} / \mathrm{kg}$ dose the alpha-pinene group showed significantly lower antiinflammatory activity compared to the $0.50 \mathrm{~mL} / \mathrm{kg}$ dose. The medium effective dose $\left(\mathrm{ED}_{50}\right)$ value of alpha-pinene was found to be $0.039 \mathrm{~mL} / \mathrm{kg}$. 
Table 2. Effects of alpha-pinene on rat paw edema.

\begin{tabular}{llll}
\hline Groups & Dose & Paw edema (mL \%) & Inhibition (\%) \\
\hline Control-I (ISS) & $0.1 \mathrm{~mL}$ & $1.043 \pm 0.127$ & - \\
Control-II (ethyl alcohol) & $0.1 \mathrm{~mL}$ & $0.988 \pm 0.112$ & - \\
Indomethacin & $3 \mathrm{mg} / \mathrm{kg}$ & ${ }^{a b} 0.024 \pm 0.061$ & 87.44 \\
Alpha-pinene & $0.05 \mathrm{~mL} / \mathrm{kg}$ & ${ }^{\mathrm{c}} 0.845 \pm 0.109$ & 18.97 \\
Alpha-pinene & $0.10 \mathrm{~mL} / \mathrm{kg}$ & ${ }^{c} 0.672 \pm 0.051$ & 35.57 \\
Alpha-pinene & $0.25 \mathrm{~mL} / \mathrm{kg}$ & ${ }^{\mathrm{abc}} 0.617 \pm 0.073$ & 40.83 \\
Alpha-pinene & $0.50 \mathrm{~mL} / \mathrm{kg}$ & ${ }^{\mathrm{abcd}} 0.413 \pm 0.069$ & 60.34 \\
\hline$F$ value & & 17.750 & \\
\hline$p$ value & 0.000 \\
\hline
\end{tabular}

Data is presented as mean \pm standard error of the mean $(n=6)$.

$\mathrm{ED}_{50}: 0.039 \mathrm{~mL} / \mathrm{kg}$.

Post-hoc Tukey's HSD and Dunnet tests:

$\mathrm{a}: p<0.05$ compared to control-I (ISS) group,

$\mathrm{b}: p<0.05$ compared to control-II (ethyl alcohol) group,

$c: p<0.05$ compared to indomethacin group,

$\mathrm{d}: p<0.05$ compared to alpha-pinene $0.05 \mathrm{~mL} / \mathrm{kg}$.

\section{Hypoglycemic activity}

The fasting blood glucose levels of the alloxan diabetic mice are presented in Table 3. Table 4 demonstrate the levels of fasting blood glucose in normal mice. It was determined that alpha-pinene significantly decreased fasting blood glucose levels at the $2^{\text {nd }}$ and $24^{\text {th }}$ hours. It was observed that alpha-pinene significantly increased fasting blood glucose levels in healthy mice at the $1^{\text {st }}$ and $2^{\text {nd }}$ hours.

Table 3. Effects of alpha-pinene on fasting blood glucose levels in diabetic mice.

\begin{tabular}{llllll}
\hline \multirow{2}{*}{ Groups } & \multicolumn{6}{l}{ Fasting blood glucose $(\mathbf{m g} / \mathbf{d L})$} \\
\cline { 2 - 6 } & $\begin{array}{l}\text { Before } \\
\text { treatment }\end{array}$ & $\mathbf{1}^{\text {st }}$ hour & $\mathbf{2}^{\text {nd }}$ hour & $\mathbf{4}^{\text {th }}$ hour & $\mathbf{2 4}^{\text {th }}$ hour \\
\hline Control (ISS) & $337.2 \pm 23.4$ & $318.4 \pm 25.3$ & $308.0 \pm 34.2$ & $225.0 \pm 34.4$ & $205.4 \pm 19.3$ \\
\hline Glibenclamide & $267.3 \pm 37.7$ & $197.8 \pm 47.3$ & ${ }^{a} 150.5 \pm 39.7$ & ${ }^{\mathrm{a}} 101.8 \pm 10.6$ & ${ }^{\mathrm{a}} 90.1 \pm 15.4$ \\
\hline Alpha-pinene & $290.4 \pm 17.4$ & $306.1 \pm 37.0$ & ${ }^{\mathrm{a}} 196.1 \pm 26.3$ & ${ }^{\mathrm{b}} 170.7 \pm 25.5$ & ${ }^{\mathrm{a}} 137.6 \pm 31.4$ \\
\hline$F$ values & 1.539 & 2.827 & 5.291 & 5.786 & 6.865 \\
\hline$p$ values & 0.247 & 0.091 & 0.018 & 0.014 & 0.009 \\
\hline
\end{tabular}

Data is represented as mean \pm standart error of the mean.

Post-hoc LSD test:

a: $\mathrm{p}<0.05$ compared to ISS group.

b: $\mathrm{p}<0.05$ compared to glibenclamide group. 
Table 4. Effects of alpha-pinene on fasting blood glucose levels in healthy mice.

\begin{tabular}{llllll}
\hline \multirow{2}{*}{ Groups } & \multicolumn{5}{l}{ Fasting blood glucose $(\mathbf{m g} / \mathbf{d L})$} \\
\cline { 2 - 6 } & $\begin{array}{l}\text { Before } \\
\text { treatment }\end{array}$ & $\mathbf{1}^{\text {st }}$ hour & $\mathbf{2}^{\text {nd }}$ hour & $\mathbf{4}^{\text {th }}$ hour & $\mathbf{2 4}^{\text {th }}$ hour \\
\hline Control (ISS) & $91.50 \pm 12.8$ & $72.75 \pm 7.2$ & $60.50 \pm 4.1$ & $61.25 \pm 4.1$ & $54.50 \pm 3.0$ \\
\hline Glibenclamide & ${ }^{\mathrm{a}} 68.75 \pm 01.3$ & $59.25 \pm 4.8$ & $59.00 \pm 3.6$ & $53.25 \pm 2.9$ & $49.75 \pm 2.0$ \\
\hline Alpha-pinene & ${ }^{\mathrm{b}} 96.0 \pm 03.8$ & ${ }^{\mathrm{ab}} 102.3 \pm 10.8$ & ${ }^{\mathrm{ab}} 79.6 \pm 4.2$ & ${ }^{\mathrm{b}} 76.6 \pm 7.3$ & $73.5 \pm 11.7$ \\
\hline F values & 4.274 & 6.019 & 8.155 & 4.059 & 2.060 \\
\hline$P$ values & 0.042 & 0.017 & 0.007 & 0.048 & 0.174 \\
\hline
\end{tabular}

Data is represented as mean \pm standart error of the mean.

Post-hoc LSD test:

a: $\mathrm{p}<0.05$ compared to ISS group.

b: $\mathrm{p}<0.05$ compared to glibenclamide group.

In this work, the $\mathrm{LD}_{50}$ dose of alpha-pinene, a major component of the essential oil of Foeniculum vulgare Mill. was determined to be $2.076 \mathrm{~mL} / \mathrm{kg}$.

The current study clearly demonstrated the in vivo anti-inflammatory effect of alpha-pinene at doses of $0.25 \mathrm{~mL} / \mathrm{kg}$ and $0.50 \mathrm{~mL} / \mathrm{kg}$. The $\mathrm{ED}_{50}$ dose of alphapinene related to its anti-inflammatory activity was found to be $0.039 \mathrm{~mL} / \mathrm{kg}$ for its.

It has been reported that Bupleurum fruticescens, Salvia species and Helichyrisum species essential oils had anti-inflammtory effects. The anti-inflammatory activity shown by the essential oil can be attributed to the two major components-alpha-pinene and beta-caryophyllene ${ }^{15-17}$. The results of these studies are consistent with those of the current study. Zhou et al. reported that alpha-pinene inhibits the nuclear translocation of NF-kappa B induced by lipopolysaccharide (LPS) in THP-1 cells ${ }^{18}$. The transcription factor NF-kappa B plays a pivotal role in the activation of multiple inflammatory molecules ${ }^{19}$. Kim et al claimed that alpha-pinene exhibits anti-inflammatory activity through the suppression of mitogen-activated protein kinases (MAPKs) and the nuclear factor-kappa B $(\mathrm{NF}-\kappa \mathrm{B})$ pathway in mouse peritoneal macrophages ${ }^{20}$. It can be suggested that alpha-pinene shows its anti-inflammatory effect through the NF-kappa B. Rufino et al. reported that at noncytotoxic concentrations, (+)- $\alpha$-pinene elicited the most potent inhibition of the IL-1 $\beta$-induced inflammatory and catabolic pathways, namely, NF- $\mathrm{BB}$ and JNK activation and the expression of the inflammatory (iNOS) and catabolic (MMP-1 and -13) genes in human chondrocytes ${ }^{21}$. 
It is found that alpha-pinene increased fasting blood glucose levels in healthy mice significantly at the $1^{\text {st }}$ and $2^{\text {nd }}$ hours. However, since these values are within normal limits the increments in fasting blood glucose levels induced by alphapinene, these observed values are considered to have no clinical significance. In addition, the results show that alpha-pinene caused mild hypoglycemic activity in the diabetic mice at the $2^{\text {nd }}$ and $24^{\text {th }}$ hours investigating. There is no study of the hypoglycemic activity of alpha-pinene in the literature. For this reason, it is not possible to comment about the mechanism of its the hypoglycemic activity. Further investigations must be conducted to reveal the mechanisms of the antiinflammatory and hypoglycemic activities of alpha-pinene.

In conclusion, the current study shows that alpha-pinene had anti-inflammatory and hypoglycemic activities in vivo.

\section{REFERENCES}

1. Akgül, A. (1993) Spice Science \& Technology. (1st edn). Publication of Food Technology Association: Ankara-Turkey, p; 96-98.

2. Pamuk, H.A. (1998) The Encyclopedia of Herbal Medicine. Pamuk Publication: IstanbulTurkey, pp; 272-543.

3. Özbek H. Investigation of The Level of The Lethal Dose 50 (LD50) and The Hypoglycemic Effect in Healthy and Diabetic Mice of Foeniculum vulgare Mill. Fruit Essential Oil Extract. Van Med.J. 2002, 9(4), 98-103.

4. Özbek, H., Öztürk, M., Bayram, İ., Uğraş, S. \& Çitoğlu, G.S. Hypoglycemic and Hepatoprotective Effects of Foeniculum vulgare Miller Seed Fixed Oil Extract in Mice and Rats. East. J. Med. 2003, $8(2), 35-40$.

5. Özbek, H., Uğraş, S., Dülger, H., Bayram, İ., Tuncer, İ., Öztürk, G. \& Öztürk, A. Hepatoprotective effect of Foeniculum vulgare essential oil. Fitoterapia, 2003, 74(3), 317-319.

6. Özbek, H., Uğraş, S., Bayram, İ., Uygan, İ., Erdoğan, E., Öztürk, A. \& Huyut, Z. Hepatoprotective effect of Foeniculum vulgare essential oil: A carbon-tetrachloride induced liver fibrosis model in rats. Scandinavian J. Laboratuary Animal Sci. 2004, 31(1), 9-17.

7. Özbek, H. The anti-inflammatory activity of the Foeniculum vulgare L. essential oil and investigation of its median lethal dose in rats and mice. Int. J. Pharmacol. 2005, 1(4), 329-331.

8. Simándi, B., Deák, A., Rónyani, E., Yanxiang, G., Veress, T., Lemberkovics, E., Then, M., SassKiss, A. \& Vamos-Falusi, Z. Supercritical carbon dioxide extraction and fractionation of Fennel oil. J. Agric. Food Chem. 1999, 47, 1635-1640.

9. Litchfield, J.T. \& Wilcoxon, F.W.J. A simplified method of evaluating dose-effect experiments. J. Pharmacol. Exp. Ther. 1949, 96, 99-113.

10. Kouadio, F., Kanko, C., Juge, M., Grimaud, N., Jean, A., N’Guessan, Y.T. \& Petit, J.Y. Analgesic and anti-inflammatory activities of an extract from Parkia biglobosa used in traditional medicine in the Ivory Coast. Phytother. Res. 200o, 14, 635-637.

11. Winter, C.A. Risley, E.A. \& Nuss, G.W. Carrageenin-induced edema in hind paw of the rats as an assay for anti-inflammatory drugs. Proceedins of the Society for Exp. Biol. Med. 1962, $111,544-547$. 
12. Rimbau, V., Cerdan, C. \& Vila, R. Anti-inflammatory activity of some extracts from plants used in the traditional medicine of North-African countries (II). Phytother. Res. 1999, 13, 128132.

13. Rodriguez, H., Perez, R.M., Muñoz, H., Perez, C. \& Miranda, R. Inducción de diabetes en raton por medio de aloxana. Acta Med. 1975, 9, 33-36.

14. Singh, S.N., Vats. P., Suri, S., Shyam, R., Kumria, M.M., Ranganathan, S. \& Sridharan, K. Effect of an antidiabetic extract of Catharanthus roseus on enzymic activities in streptozotocin induced diabetic rats. J. Ethnopharmacol. 2001, 76, 269-277.

15. Martin, S., Padilla, E., Ocete, M.A., Galvez. J., Jimenez, J. \& Zarzuelo, A. Anti-inflammatory activity of the essential oil of Bupleurum fruticescens. Planta Med. 1993, 59(6), 533-536.

16. Kamatou, G.P., Viljoen, A.M., Gono-Bwalya, A.B., Zyl, R.L., Vuuren, S.F., Lourens, A.C., Baser, K.H., Demirci, B., Lindsey, K.L., Staden, J.V. \& Steenkamp, P. The in vitro pharmacological activities and a chemical investigation of three South African Salvia species. J. Ethnopharmacol. 2005, 102(3), 382-390.

17. Lourens, A.C., Reddy, D., Baser, K.H., Viljoen, A.M. \& Van Vuuren, S.F. In vitro biological activity and essential oil composition of four indigenous South African Helichrysum species. $J$. Ethnopharmacol. 2004, 95(2-3), 253-258.

18. Zhou, J.Y., Tang, F.D., Mao, G.G. \& Bian, R.L. Effect of alpha-pinene on nuclear translocation of NF-kappa B in THP-1 cells. Acta Pharmacol Sin. 2004, 25(4), 480-484.

19. Makarov, S.S., Johnston, W.N., Olsen, J.C., Watson, J.M., Mondal, K., Rinehart, C. \& Haskill, J.S. NF-kappa B as a target for anti-inflammatory gene therapy: suppression of inflammatory responses in monocytic and stromal cells by stable gene transfer of I kappa B alpha cDNA. Gene Ther. 1997, 4(8), 846-852.

20. Kim DS, Lee HJ, Jeon YD, Han YH, Kee JY, Kim HJ, Shin HJ, Kang J, Lee BS, Kim SH, Kim SJ, Park SH, Choi BM, Park SJ, Um JY, Hong SH. Alpha-Pinene Exhibits Anti-Inflammatory Activity Through the Suppression of MAPKs and the NF- $\kappa$ B Pathway in Mouse Peritoneal Macrophages. Am J Chin Med. 2015, 43(4), 731-742.

21. Rufino AT, Ribeiro M, Judas F, Salgueiro L, Lopes MC, Cavaleiro C, Mendes AF. Anti-inflammatory and chondroprotective activity of (+)- $\alpha$-pinene: structural and enantiomeric selectivity. J Nat Prod. 2014, $77(2)$, 264-269. 